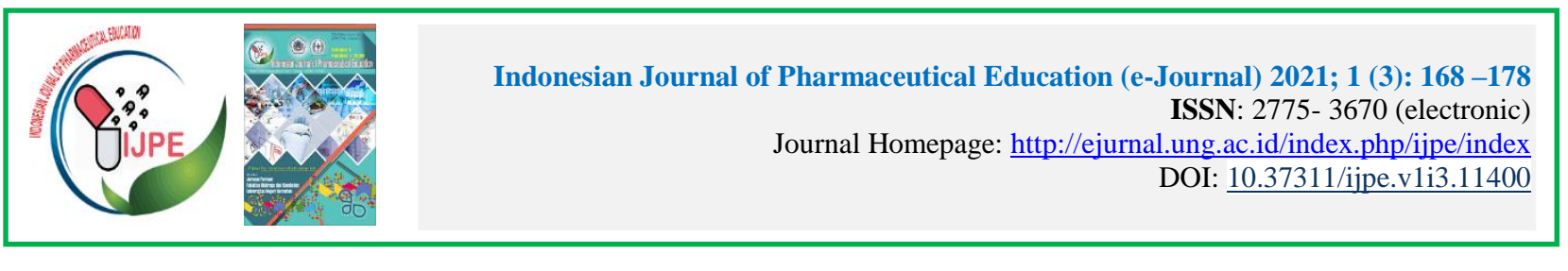

\title{
Formulasi, Karakterisasi, Dan Evaluasi Drops Liquid Self Nano- Emulsifying Drug Delivery System (SNEDDS) Astaxanthin
}

\section{Robert Tungadi ${ }^{1}$, Nur Ain Thomas ${ }^{2}$,Wanda Gita Van Gobel ${ }^{3 *}$ \\ 1,2,3 Jurusan Farmasi, Fakultas Olahraga dan Kesehatan, Universitas Negeri Gorontalo, Gorontalo *E-mail: wandagobel999@gmail.com}

Article Info:

Received: 14 Juli 2021

in revised form: 30 Juli 2021

Accepted: 25 Agustus 2021

Available Online: 25 Agustus 2021

Keywords:

SNEDDS; Astaxanthin;

Nanoparticle; Characterization

Corresponding Author:

Wanda Gita Van Gobel

Jurusan Farmasi

Fakultas Olahraga dan

Kesehatan

Universitas Negeri Gorontalo

E-mail:

wandagobel999@gmail.com
SNEDDS are isotropic mixtures of oil, surfactant, and cosurfactant that produce spontaneous nanoemulsions once they make contact with gastric juices in order to increase the solubility of active pharmaceutical ingredients. One of the active pharmaceutical ingredients with low solubility is Astaxanthin. This research aims at formulating, characterizing, and evaluating SNEDDS containing Astaxanthin in the form of droplets. This research is a laboratory experiment. SNEDDS containing Astaxanthin droplets are made in 3 formulas using the ratio of surfactants and cosurfactants which are characterized to produce F1, F2, and F3 transmittance values of $91 \%, 90 \%$, and $95 \%$, respectively. Furthermore, the F1 particle size value of $183.75 \mathrm{~nm}$ obtains a PDI value of 0.272 , the F2 particle sizevalue of $195.25 \mathrm{~nm}$ obtains a PDI value of 0.341 , and the F3 particle size value of 105.75 $\mathrm{nm}$ obtains a PDI value of 0.392 . This signifies that the absorption efficiency of F1, F2, and F3 are $94.62 \%, 94.35 \%$, and $95.57 \%$, respectively. The evaluation reveals the insignificant changes in the emulsion viscosities of SNEDDS containing Astaxanthin liquid drop after having received a stability test for 28 days using Paired T. Test data analysis $(p<0.05)$. The research findings show that the F3 of $72 \%$ surfactant and $18 \%$ co-surfactant concentrations are the best formula in producing SNEDDS. It concludes thar the higher the surfactant concentration produced, the greater the ability to, oil droplets resulting in obtaining small partidles and high absorption efficiency.

\section{Copyright \\ Copyright (C2021IJPE- \\ UNGThisopenaccessarticleisdistributedunderaCreativeCommonsAttribution(CC-BY-NC-SA)4.0International}

How to cite (APA $6^{\text {th }}$ Style):

Tungadi, R., Thomas, N.A., Gobel, W.G.V. (2021). Formulasi, Karakterisasi, Dan Evaluasi Drops Liquid Self Nano-

Emulsifying Drug Delivery System (SNEDDS) Astaxanthin Indonesian Journal of Pharmaceutical (e-Journal),1(3), 168-178. 


\begin{abstract}
ABSTRAK
SNEDDS merupakan campuran isotropik antara minyak, surfaktan, dan ko-surfaktan yang membentuk nanoemulsi secara spontan ketika kontak dengan cairan lambung sehingga meningkatkan kelarutan zat aktif. Salah satu zat aktif yang memiliki kelarutan rendah adalah astaxanthin. Penelitian ini bertujuan untuk memformulasikan, mengkarakterisasi dan mengevaluasi SNEDDS Astaxanthin dalam bentuk sediaan larutan drops. Penelitian ini merupakan penelitian eksperimental laboratorium. Drops liquid SNEDDS Astaxanthin yang dibuat dalam 3 formula dengan menggunakan perbandingan surfaktan dan ko-surfaktan yang dikarekterisasikan menghasilkan nilai transmitan $\mathrm{F}_{1} 91 \%, \mathrm{~F}_{2} 90 \%$, dan $\mathrm{F}_{3}$ 95\%, dengan nilai ukuran partikel $\mathrm{F}_{1} 183,75$ $\mathrm{nm}$ dengan nilai PDI 0,272, $\mathrm{F}_{2} 195,25 \mathrm{~nm}$ dengan nilai PDI 0,341, dan $\mathrm{F}_{3} 105,75 \mathrm{~nm}$ dengan nilai PDI 0,392. Sehingga nilai efisien penjerapan $F_{1} 94,62 \%, F_{2} 94,35 \%$, dan $F_{3} 95,57 \%$. Evaluasi sediaan menunjukkan tidak adanya perubahan yang signifikan pada viskositas dan waktu emulsifikasi drop liquid SNEDDS Astaxanthin setelah melalui uji stabilitas selama 28 hari dengan menggunakan analisis data Paired T-Test $(\mathrm{p}<0,05)$. Hasil penelitian menunjukkan bahwa $\mathrm{F}_{3}$ dengan kosentrasi surfaktan $72 \%$ dan ko-surfaktan $18 \%$ adalah formula terbaik dalam membentuk SNEDDS. Dapat disimpulkan semakin tinggi kosentrasi surfaktan maka semakin besar kemampuannya untuk menurukan tegangan antar muka tetesan minyak sehingga memperoleh ukuran partikel yang kecil dan nilai efisiensi penjerpan yang tinggi.
\end{abstract}

Kata Kunci: SNEDDS; Astaxanthin; Nanopartikel; Karakterisasi

\title{
1. Pendahuluan
}

Pengembangan terkini sistem nanoemulsi untuk aplikasi oral melalui saluran gastrointestinal adalah teknologi auto-emulsifikasi (Self-nanoemulsifying drug delivery systems (SNEDDS). Secara umum SNEDDS merupakan metode penghantaran obat melalui pembuatan campuran isotropik minyak, surfaktan, kosurfaktan, dan obat yang secara spontan membentuk nanoemulsi minyak dalam air melalui agitasi ringan ketika mengalami kontak dengan fase air dalam saluran cerna dan menghasilkan tetesan yang berukuran nanometer [12].

Metode SNEDDS memiliki kelebihan diantaranya meningkatkan bioavailabilitas zat aktif obat melalui penggunaan secara oral, meningkatkan laju disolusi dan absorpsi zat aktif di dalam tubuh terutama untuk obat-obat yang memiliki kelarutan rendah di dalam air atau obat yang bersifat lipofilik seperti obat-obat yang tergolong dalam BCS (Biopharmaceutical drug Classification System) kelas II dimana obat tersebut memiliki permeabilitas tinggi tetapi kelarutannya rendah sehingga dapat menurunkan bioavailabilitas obat.

Salah satu zat aktif yang termasuk golongan BCS kelas 2 adalah astaxanthin. Astaxanthin merupakan karotenoid utama yang terdapat dalam organisme aquatik atau hewan-hewan yang hidup diair seperti udang, kepiting, ikan salmon, dan lobster serta mikroalga Haematococcus puvialis.

Dalam beberapa penelitian menyebutkan bahwa astaxanthin merupakan super antioksidan, salah satunya penelitian experimen in vivo menyatakan bahwa astaxanthin 14 hingga 60 kali lebih kuat dari pada antioksidan yang lain [2]. Untuk itu banyak manfaat astaxanthin dalam kesehatan salah satunya dapat meningkatkan sistem imun hal ini dengan cara meningkatkan produksi imunoglobulin sebagai respon terhadap stimulus polikronal dengan dosis harian $4 \mathrm{mg} /$ hari yang 
bertindak sebagai antiokidan yang bermanfaat untuk meningkatkan sistem imun dan menangkal radikal bebas, ada begitu banyak manfaat astaxanthin dalam tubuh [6,10]

Dalam peningkatan bioavaibilitas dari astaxanthin telah banyak dikembangkan mulai dari formulasi berbasis lipid hingga nano emulsi, salah satu penelitian sebelumnya mengembangkan bioavabilitas astaxanthin akan tetapi pada penelitiannya astaxanthin dibuat dalam self nanoemulsifying atau pembentukan emulsi yang secara spontan dengan komponen minyak pembawa minyak bunga matahari yang dilakukan karakterisasi dengan hasil didapatkan sesuai dengan persyaratan [10]

Berdasarkan uraian diatas, maka penelitian dilakukan untuk memformulasikan, mengkarakterisasi dan mengevaluasi drops Liquid Self Nano Emulsifying Drug Delivery System Astaxanthin memenuhi persyaratan SNEDDS.

\section{Metode Penelitian}

\section{Alat dan Bahan}

Alat-alat yang digunakan pada penelitian ini adalah Aluminium Foil, Batang Pengaduk, Gelas Beaker (Pyrex), Gelas Ukur (Pyrex), Magnetic Stirrer (Cimarec), Neraca Analitik (Digital Scale 8068- Series), PSA (Horiba SZ-100), Pipet Mikro (Physio Care), Pipet Tetes, Sendok Tanduk, Sentrifugasi (Purispin6), Sonikasi (Krisbow), Spatula, Spektrofotometer UV-VIS (Genesys 20) , Stop Wacth , Tabung Ependrof, Viscometer Brookfield ,Vortex (Scilogex)

Bahan yang digunakan pada penelitian ini adalah Aquades, Alfa Tokoferol, Asam Benzoat, Asam Oleat, Astaxathin (PT Hamburg Jerman), Metanol, Kertas Saring, Propilen Glikol, Polietilen Glikol 400, Tween 20, Tween 80, Tisu

Prosedur Kerja

Pembuatan Kurva Baku Astaxanthin

Dibuat larutan stok Astaxanthin dengan melarutkan $10 \mathrm{mg}$ astaxanthin kedalam $10 \mathrm{~mL}$ metanol. Kemudian dilakukan pengenceran untuk membuat larutan standar dengan berbagai variasi yaitu, 10 ppm, 15 ppm, 20 ppm, 25 ppm dan 30 ppm. Setelah itu dibaca absorbansinya menggunakan alat Spektrofometer UV-Vis dengan panjang gelombang dari astaxanthin yaitu $470 \mathrm{~nm}$.

Uji Kelarutan

Diukur masing masing bahan sebanyak $1 \mathrm{~mL}$ minyak (asam oleat, minyak zaitun, dan minyak VCO), surfaktan (tween 20 dan tween 80) dan Ko-surfaktan (propilen glikol dan PEG 400) lalu dimasukkan kedalam tabung eppendorf tube, dan ditambahkan $10 \mathrm{mg}$ Astaxanthin ke masingmasing bahan, di vortex selama 15 menit setiap harinya selama 72 jam. Kemudian setelah 72 jam sampel disentrifugasi selama 26 menit dengan kecepatan $6000 \mathrm{rpm}$ pada suhu ruang. Diambil supernatanya dan dianalisis dengan spektrofotometer UV-Vis untuk mengetahui kosentrasi dan kelarutan astaxanthin. Berdasarkan hasil tersebut dipilih bahan yang akan ditetapkan sebagai fase minyak, surfaktan dan ko-surfaktan.

Optimasi Formulasi SNEDDS

Berdasarkan hasil kelarutan digunakan asam oleat sebagai fase minyak, tween 20 dan tween 80 sebagai surfaktan, dan propilenglikol sebagai ko-surfaktan. Kemudian dilakukan optimasi formulasi dengan rasio perbandingan Minyak : Mix Surfaktan (1:9) dan Rasio Perbandingan Mix surfaktan (Surfaktan : Ko-Surfaktan) antara Tween 20 : Propilen glikol dan Tween 80 : Propilen glikol 
yang dibuat (1:1) (2:1) (3:1) dan (3,2:0,8). Pembuatan dilakukan dengan mencampurkan komponen Surfaktan : Ko-Surfaktan terlebih dahulu kemudian ditambahkan komponen minyak dengan menggunakan magnetik stirer selama 30 menit, disonikasi selama 10 menit. Hasil pencampuran didiamkan selama 24 jam pada suhu ruangan untuk dilihat homogenitasnya.

Formulasi SNEDDS Astaxanthin

Dalam formulasi sediaan liquid SNEDDS dilakukan terlebih dahulu yaitu propilen glikol ditambahkan kedalam tween 20 dengan menggunakan magnetik stirrer kecepatan $250 \mathrm{rpm}$. Setelah homogen, ditambahkan asam oleat (fase minyak) yang telah bercampur dengan alfa-tokoferol distirer dengan kecepatan rendah, lalu ditambahkan astxanthin dan diaduk dengan menggunakan pengaduk magnetik selama 30 menit, kemudian disonikasi selama 1 jam.

Karakterisasi SNEDDS Astaxanthin

Uji \% transmitan

Cara pengukuran nilai transmitan yaitu sebanyak $100 \mu \mathrm{L}$ calon formula SNEDDS ditambah akuades hingga volume akhir $5 \mathrm{~mL}$ kemudian divorteks selama 1 menit. Kemudian diukur nilai transmitannya menggunakan spektrofotometri pada panjang gelombang $650 \mathrm{~nm}$ dengan blanko aquades untuk mengetahui tingkat kejernihannya. Parameter nilai transmitan yaitu nilai absorbansi yang mendekati $100 \%$ menunjukkan bahwa ukuran tetesan dispersi yang dihasilkan oleh SNEDDS telah mencapai ukuran nanometer, yang secara visual tampak dari transparansi sistem yang terbentuk [4]

Pengukuran Ukuran Partikel

Pengukuran ukuran partikel rata-rata dan distribusi ukuran partikel SNEDDS astaxanthin dilakukan dengan menggunakan Particle Size Analyzer (PSA).

Pengukuran Efisiensi Penjerapan

Penentuan efisiensi penjeratan berfungsi untuk mengetahui jumlah Astaxanthin yang terjerat dalam SNEDDS. Sebanyak $200 \mathrm{mg}$ formula SNEDDS astaxanthin disentrifugasi pada kecepatan 3000 rpm selama 15 menit. Astaxanthin bebas akan mengendap, sehingga Astaxanthin yang terjerat bisa dianalisis dengan menggunakan spektrofotometer UV-VIS pada panjang gelombang $470 \mathrm{~nm}$ [10] Evaluasi Drops Liquid SNEDDS Astaxanthin

Uji Organoleptik

Sediaan liquid SNEDDS dilakukan pengamatan secara visual mengenai warna, bau, dan pemisahan fase sediaan menggunakan indra penglihatan dan penciuman.

Viskositas

Pengukuran viskositas dilakukan dengan menggunakan viscometer Brookfield dimana wadah disi $50 \mathrm{~mL}$ SNEDDS astaxanthin kemudian dipasang spindle dan dinyalakan motor spindle sampai spindle itu berputar dalam jurnal Eid et al., (2014) kecepatan spindle dalam pengukuran viskositas yaitu $100 \mathrm{rpm}$ dengan interval waktu 1 menit. Dengan Nilai parameter viskositas ini adalah 30-40 cP (Abdullah et al, 2010)

Penentuan Waktu emulsifikasi

Penentuan waktu emulsifikasi dilakukan dengan cara sebanyak $1 \mathrm{ml}$ formula SNEDDS Astaxanthin diteteskan kedalam gelas beaker yang berisi media aquades diaduk dengan bantuan magnetik stirrer dengan kecepatan 100 rpm. Pengamatan dilakukan terhadap waktu yang 
diperlukan sejak awal penetesan SNEDDS kedalam media hingga terbentuk nanoemulsi. Dengan parameter waktu emulsifikasi yang stabil yaitu kurang dari 2 menit (Wirnarti et al,.2018).

Uji Stabilitas dengan metode Freeze Thaw

Sediaan SNEDDS disimpan pada suhu $-4^{\circ} \mathrm{C}$ selama 48 jam kemudian disimpan pada suhu ruang $40^{\circ} \mathrm{C}$ selama 48 jam. Proses ini diulang hingga 7 siklus, lalu diamati perubahan fisik seperti warna, bau, dan pemisahan

Analisis Data

Analisis data dalam evaluasi sediaan digunakan uji stastik dengan menggunakan uji paired TTest pada uji viskositas dan uji waktu emulsifikasi

3. Hasil dan Pembahasan

Kurva Baku Astaxanthin

Berdaraskan hasil penilaian absorbansi Astaxanthin (Tabel 1) dengan 5 kosentrasi yaitu $10,15,20,25$,dan 30 dengan menggunakan panjang gelombang astaxanthin $470 \mathrm{~nm}$ didapat persamaan garis $\mathrm{y}=0,0257 \mathrm{x}-0,1136$ dengan nilai $\mathrm{r}^{2}=0,9965$.

Tabel 1 Hasil Absorbansi Astaxanthin

\begin{tabular}{cc}
\hline $\begin{array}{c}\text { Kosentrasi } \\
\text { (ppm) }\end{array}$ & $\begin{array}{c}\text { Absorbansi } \\
(\lambda=470 ~ \mathbf{~ m})\end{array}$ \\
\hline $\mathbf{1 0}$ & 0.152 \\
$\mathbf{1 5}$ & 0.267 \\
$\mathbf{2 0}$ & 0.396 \\
$\mathbf{2 5}$ & 0.512 \\
$\mathbf{3 0}$ & 0.671 \\
\hline
\end{tabular}

Data absorbansi yang dihasilkan sudah tergolong baik, karena semua seri kadar dari nilai yang terkecil hingga yang terbesar memiliki nilai absorbansi sebesar 0,1 - 0,7, sedangkan nilai korelasi yang didapat yaitu sebesar 0,9965 . nilai koefesien korelasi yang memenuhi persyaratan lebih dari 0,9770 atau hampir mendekati 1 sehingga hasil yang didapatkan linear antara kosentrasi dan absorbansi [14]

Uji Kelarutan

Tabel 2 Hasil Uji Kelarutan bahan dengan Astaxanthin

\begin{tabular}{lll}
\hline Bahan & Fungsi & $\begin{array}{l}\text { Kelarutan } \\
(\mathbf{m g} / \mathrm{mL})\end{array}$ \\
\hline Asam Oleat & Fase minyak & $198,91 \mathrm{mg} / \mathrm{mL}$ \\
Minyak zaitun & Fase minyak & $182,1 \mathrm{mg} / \mathrm{mL}$ \\
Minyak VCO & Fase minyak & $172,22 \mathrm{mg} / \mathrm{mL}$ \\
Tween 20 & Surfaktan & $172,45 \mathrm{mg} / \mathrm{mL}$ \\
Tween 80 & Surfaktan & $169,33 \mathrm{mg} / \mathrm{mL}$ \\
Propilen glikol & Ko-surfaktan & $174,78 \mathrm{mg} / \mathrm{mL}$ \\
PEG 400 & Ko-surfaktan & $157,97 \mathrm{mg} / \mathrm{mL}$ \\
\hline
\end{tabular}


Tabel 2 Menunjukkan hasil kelarutan komponen bahan penyusun SNEDDS yang memiliki kelarutan tertinggi dengan astxanthin yaitu asam oleat sebagai fase minyak, tween 20 sebagai surfaktan dan propilen glikol sebagai ko-surfaktan.

Asam Oleat sebagai fase minyak memiliki kelarutan tertinggi dalam melarutkan astaxanthin, hal ini karena Asam oleat memiliki nilai koefesien partisi lebih dari 6,5 sehingga asam oleat mudah berikatan dengan gugus lipofilik senyawa lain. Selain itu, tween 20 memiliki nilai kelarutan lebih tinggi dibandingkan tween 80. Hal ini karena tween 20 memiliki nilai HLB 16,7 yang cenderung hidrofilik dan bersifat nonionik, membuat tween 20 memiliki kemampuan yang baik dalam melarutkan astaxanthin. Sedangkan untuk ko-surfaknya propilen glikol lebih memiliki nilai kelarutan yang lebih tinggi dibandingkan PEG 400 hal ini mengindikasikan bahwa propilen glikol memiliki polaritas yang sama dengan astaxanthin

Optimasi Basis SNEDDS

Tabel 3 menunjukan Menunjukkan hasil optimasi basis SNEDDS dengan perbandingan minyak, surfaktan, dan ko-surfaktan, optimasi basis ini dilakukan dengan memvariasikan penggunaan surfaktan yaitu tween 20 dan tween 80 dan memvariasikan perbandingan rasio mix surfaktan sehingga menghasilkan basis SNEDDS dengan tampilan fisik yang jernih. Hasil yang didapatkan bahwa formula B, C dan D menghasilkan tampilan fisik SNEDDS yang jernih.

Tabel 3 Optimasi Basis SNEDDS

\begin{tabular}{|c|c|c|c|}
\hline Formula & $\begin{array}{c}\text { Rasio } \\
\text { Perbandingan } \\
\text { Minyak : Mix } \\
\text { Surfaktan }\end{array}$ & $\begin{array}{c}\text { Rasio } \\
\text { Perbandingan } \\
\text { Mix surfaktan } \\
\text { (Surfaktan : Ko- } \\
\text { Surfaktan) }\end{array}$ & $\begin{array}{l}\text { Evaluasi } \\
\text { Kejernihan }\end{array}$ \\
\hline & & \multicolumn{2}{|c|}{ Tween 20 : Propilen glikol } \\
\hline A & & $1: 1$ & Agak jernih \\
\hline B & & $2: 1$ & Jernih \\
\hline C & & $3: 1$ & Jerrnih \\
\hline \multirow[t]{2}{*}{$\mathrm{D}$} & $1: 9$ & $3,2: 0,8$ & Jernih \\
\hline & & \multicolumn{2}{|c|}{ Tween 80 : Propilen glikol } \\
\hline E & & $3,2: 0,8$ & Agak keruh \\
\hline $\mathrm{F}$ & & $3: 1$ & Agak Keruh \\
\hline G & & $2: 1$ & Keruh \\
\hline $\mathrm{H}$ & & $1: 1$ & Keruh \\
\hline
\end{tabular}

Formula B, C dan D menggunakan surfaktan tween 20 dan ko-surfaktan propilen glikol lebih mampu menghasilkan campuran yang homogen dan jernih pada penambahan asam oleat dibandingkan pada penggunaan tween 80 dengan propilen glikol. Sesuai literature tween 20 dan propilen glikol mempunyai bobot molekul dan viskositas yang lebih rendah dan struktur yang lebih sederhana dibandingkan tween 80 dan propilen glikol, sehingga dapat lebih mudah berinteraksi dengan astaxanthin. Adanya gugus hidroksil bebas dan oksigen bebas pada astaxanthin 
yang berinteraksi dengan SNEDDS yang akan membentuk ikatan hidrogen yang membuat astaxanthin menjadi lebih larut $[5,13]$

Formulasi Drops Liquid SNEDDS Astaxanthin

Tabel 4. Menunjukkan hasil formulasi SNEDDS dengan dosis astaxanthin $4 \mathrm{mg}$, kosentrasi minyak $10 \%$ dan kosentrasi antioksidan $0,15 \%$ terhadap 3 formula, dengan memvariasikan kosentrasi surfaktan (tween 20) yaitu formula 1 (72\%), formula 2 (67,5\%), formula $3(59 \%)$ dan kosurfaktan (propilen glikol) formula 1 (18\%), formula 2 (22,5\%), dan formula $3(31 \%)$ menghasilkan tampilan fisik SNEDDS yang jernih.

\section{Tabel 4 Hasil Formulasi Drops Liquid SNEDDS Astaxanthin}

\begin{tabular}{cccc}
\hline Bahan & \multicolumn{3}{c}{ Kosentrasi } \\
& F1 & F2 & F3 \\
\hline Astaxanthin & $4 \mathrm{mg}$ & $4 \mathrm{mg}$ & $4 \mathrm{mg}$ \\
Asam oleat & $10 \%$ & $10 \%$ & $10 \%$ \\
Tween 20 & $59 \%$ & $67,5 \%$ & $72 \%$ \\
Propilen glikol & $31 \%$ & $22,5 \%$ & $18 \%$ \\
Alfa tokoferol & $0,15 \%$ & $0,15 \%$ & $0,15 \%$ \\
Evaluasi Kejernihan & Jernih & Jernih & Jernih \\
\hline
\end{tabular}

\section{Karakterisasi SNEDDS}

Tabel 5 Menunjukkan hasil pengukuran transmitan SNEDDS Astaxanthin menggunakan Spektrofotometer UV-VIS menghasilkan ketiga formulasi diatas $90 \%$

Tabel 5 Pengukuran Persen Transmitan menggunakan Spektrofotometer

\begin{tabular}{ll}
\hline Formula & $\begin{array}{l}\text { Persen Transmitan } \\
\mathbf{( \% )}\end{array}$ \\
\hline 1 & $91 \%$ \\
2 & $90 \%$ \\
3 & $95 \%$ \\
\hline
\end{tabular}

Berdasarkan hasil yang tersaji pada tabel 5 pengujian persen transmitan yang diperoleh formula 3 memiliki nilai persen transmitan lebih tinngi dibandingkan formula 1 dan 2 . Hal ini, dikarenakan komposisi surfaktan pada formula 3 lebih banyak dibandingkan 1 dan 2 formula. Komposisi surfaktan yang lebih besar dapat mempengaruhi ukuran tetesan emulsi sehingga semakin kecil ukuran yang dihasilkan semakin jernih SNEDDS yang diperoleh maka persen transmitan semakin besar. Nilai persen Transmitan SNEDDS Astaxanthin dari ketiga formula berkisar antara 90\% - 95\% dan menghasilkan dispersi yang jernih [4].

Tabel 6 Pengukuran Ukuran partikel menggunakan PSA

\begin{tabular}{lll}
\hline Formula & Ukuran Partikel $(\mathrm{nm})$ & Indeks Polidispersitas \\
\hline 1 & $183,75 \mathrm{~nm}$ & 0,272 \\
2 & $195,25 \mathrm{~nm}$ & 0,341 \\
3 & $105,75 \mathrm{~nm}$ & 0,392 \\
\hline
\end{tabular}


Tabel 6 Menunjukkan hasil pengukuran diameter ukuran partikel SNEDDS Astaxanthin menggunakan Particle Size Analyzer menghasilkan ketiga formula ukuran partikelnya < $200 \mathrm{~nm}$ dan Indeks Polidispersitas menunjukkan keseragaman distribusi ukuran.

Berdasarkan tabel 6 hasil pengukuran ukuran partikel bahwa formula 3 menghasilkan ukuran partikel yang lebih kecil dibandingkan formula 1 dan 2. Hal tersebut dipengaruhi oleh kosentrasi surfaktan yang digunakan dalam formula 3 lebih besar dibandingkan formula 1 dan formula 2. Menurut literatur penggunaan kosentrasi surfaktan yang besar dapat mengurangi tegangan antar muka, karena surfaktan akan melingkup tetesan minyak saat teremulsi dalam air sehingga akan membentuk ukuran yang nanometer. Ukuran partikel dari ketiga formulasi berada dalam rentang $105 \mathrm{~nm}-195 \mathrm{~nm}$ yang masuk dalam rentang dari ukuran patikel SNEDDS dengan nilai indeks polidispersitas 0,272 - 0,392 yang menyatakan bahwa ketiga formula memiliki keseragam ukuran partikel. semakin kecil nilai IP (mendekati 0) artinya distribusi ukuran droplet semakin seragam [3].

Tabel 7 Pengukuran Efisiensi Penjerapan menggunakan Spektrofotometer

\begin{tabular}{ll}
\hline Formula & Efiseiensi Penjerapan (\%) \\
\hline 1 & $94,62 \%$ \\
2 & $94,35 \%$ \\
3 & $95,57 \%$
\end{tabular}

Tabel 7 Menunjukkan hasil pengukuran efisiensi penjerapan SNEDDS Astaxanthin. Dimana ketiga formula memiliki nilai efisiensi penjerapan diatas $90 \%$.

Berdasarkan tabel 4.7 hasil efisien penjerapan yang didapatkan berada dalam rentang $94 \%$ 95\% yang dapat dikatakan bahwa sistem nanoemulsi yang terbentuk mampu menjerap zat aktif sehingga kadar obat yang terdapat dalam nanoemulsi tinggi dan dapat meningkatkan sistem pengantaran obat ke target. Semakin besar nilai efisensi penjerapan maka kosentrasi obat yang terdapat dalam pembawa semakin besar [11]

Hasil Evaluasi SNEDDS Drops Astaxanthin

Tabel 8 Uji Organoleptik

\begin{tabular}{cll}
\hline Formula & \multicolumn{1}{c}{ Waktu/t (Hari) } \\
\cline { 2 - 3 } F1 & \multicolumn{1}{c}{$\mathbf{c}$ t28 } \\
& Warna : Orange & Warna : Orange \\
& Bau : Tidak berbau & Bau : Tidak berbau \\
& Fase Pemisahan : Homogen & Fase Pemisahan : Homogen \\
F2 & Warna : Orange & Warna : Orange \\
& Bau : Tidak berbau & Bau : Tidak berbau \\
& Fase Pemisahan : Homogen & Fase Pemisahan : Homogen \\
F3 & Warna : Orange & Warna : Orange \\
& Bau: Tidak berbau & Bau : Tidak berbau \\
& Fase Pemisahan : Homogen & Fase Pemisahan : Homogen \\
\hline
\end{tabular}


Tabel 4.8 Menunjukkan hasil evaluasi organoleptik formulasi drops SNEDDS Astaxanthin pada waktu ke-0 sampai ke-28 yang diletakkan pada suhu freeze-thaw, dimana ketiga formulasi memiliki tampilan yang jenih berwarna jingga, tidak berbau dan terjadi pemisahan fase.

Evaluasi organoleptik bertujuan untuk mengetahui dan mengindetifikasi penampilan fisik dari SNEDDS yang sudah dibuat. Uji organoleptis yang dilakukan meliputi: bau, warna, dan pemisahan fase. Evaluasi ini dilakukan hari pertama pembuatan sediaan sampai hari ke-28 dengan freeze thaw. SNEDDS yang dihasilkan pada formula 1, 2, dan 3 bewarna jingga, tidak memiliki bau, jernih dan tidak terjadi pemisahan fase setelah penyimpanan 28 hari. SNEDDS Astaxanthin tidak memiliki bau hal karena astaxanthin yang terlarut dalam pembawa minyak dan masuk kedalam inti misel surfaktan dan ko-surfaktan sehingga bau alami astaxanthin [10].

Tabel 4.9 Uji Viskositas

\begin{tabular}{ccc}
\hline \multirow{2}{*}{ Formula } & \multicolumn{2}{c}{ Waktu/t (hari) } \\
& t0 & t28 \\
\hline 1 & 34 & 34 \\
2 & 35 & 39 \\
3 & 37 & 40 \\
\hline
\end{tabular}

Tabel 9 Menunjukkan hasil evaluasi viskositas formulasi drops SNEDDS Astaxanthin yang dilakukan dengaan menggunakan Viskometer Brockfiel selama 7 siklus.

Evaluasi Viskositas bertujuan untuk mengetahui kosistensi sifat cairan untuk mengalir. Semakin tinggi viskositas suatu cairan maka semakin kental cairan tersebut dan semakin besar pula kekuatan yang dibutuhkan cairan tersebut untuk mengalir. Dalam sediaan SNEDDS nilai viskositas yang baik yaitu 30-40 cP. Pengujian viskositas digunakan alat berupa Viskometer Brookfiel dengan kecepatan 100 rpm dengan nomor spindle no 4.

Viskositas dari ketiga formula yang dianalisis statistik pada uji normalitas menggunakan Shapiro wilk, pada semua sampel diperoleh signifikasi $>0,05$ sehingga data tersebut terdistribusi normal. Selanjutnya dilakukan uji paired T-Test pada sediaan SNEDDS pada waktu t0 yang sebelum frezze thaw dan waktu $\mathrm{t} 28$ sesudah freeze thaw diperoleh signifikasi $>0,05$ yang dapat disimpulkan bahwa nilai viskositas SNEDDS tidak terjadi perbedaan bermakna antara t0 dan t28. Kestabilan dari nanoemulsi dipengaruhi oleh penggunaan surfaktan dan ko-surfaktan dalam menurunkan tegangan permukaan emulsi antara minyak dan air sehingga akan membentuk nanoemulsi yang stabil, viskositas yang rendah serta luas permukaan yang tinggi sehingga meningkatakan bioavabilitas obat [9].

Tabel 10 Uji waktu emulsifikasi

\begin{tabular}{ccc}
\hline \multirow{2}{*}{ Formula } & \multicolumn{2}{c}{ Waktu Waktu/t (hari) } \\
t0 & t28 \\
\hline 1 & 9 & 9 \\
2 & 11 & 16 \\
3 & 21 & 25 \\
\hline
\end{tabular}

Tabel 10 Menunjukkan hasil evaluasi waktu emulsifikasi formulasi drops SNEDDS Astaxanthin selama 7 siklus. 
Evaluasi waktu emulsifikasi merupakan parameter penting dalam SNEDDS bertujuan untuk mengetahui kecepatan formula SNEDDS membentuk emulsi secara spontan setelah kontak langsung dengan cairan gastrik. Semakin cepat waktu emulsifikasi maka akan meningkatkan absorpsi dari obatnya [7]. Jika waktu emulsifikasi yang dihasilkan kurang dari 1-2 menit maka formula SNEDDS mampu membentuk emulsi setelah langsung kontak dengan cairan gastrik, dengan menghasilkan sistem emulsi yang cukup jernih. Bila waktu emulsifikasi lebih dari 2 menit akan menghasilkan sistem emulsi yang keruh, sehingga tidak direkomendasikan untuk formulasi SNEDDS [8]

Waktu emulsifikasi ketiga formula yang dianalisis statistik pada uji normalitas menggunakan Shapiro wilk, pada semua sampel diperoleh signifikasi $>0,05$ sehingga data tersebut terdistribusi normal. Selanjutnya dilakukan uji paired T-Test pada sediaan SNEDDS pada waktu t0 yang sebelum frezze thaw dan $\mathrm{t} 28$ sesudah freeze thaw diperoleh signifikasi $>0,05$ yang dapat disimpulkan tidak terjadi perbedaan bermakna antara t0 yang sebelum frezze thaw dan $\mathrm{t} 28$ sesudah freeze thaw dalam hal pengujian waktu emulsifikasi.

4. Kesimpulan

Berdasarkan hasil penelitian formulasi drops liquid SNEDDS astaxanthin menghasilkan formula yang baik dengan menggunakan asam oleat sebagai fase minyak, tween 20 sebagai surfaktan dan propilen glikol sebagai ko-surfaktan. Hasil Karakterisasi Drops Liquid SNEDDS Astaxanthin menghasilkan nilai transmitan $\mathrm{F}_{1} 91 \%, \mathrm{~F}_{2} 90 \%$, dan $\mathrm{F}_{3} 95 \%$, dengan nilai ukuran partikel $\mathrm{F}_{1} 183,75$ nm dengan PDI 0,272, $F_{2}$ 195,25 nm dengan PDI 0,341, dan $F_{3} 105,75 \mathrm{~nm}$ dengan PDI 0,392, dan hasil perhitungan efisien penjerapan $\mathrm{F}_{1} 94,62 \%, \mathrm{~F}_{2} 94,35 \%$, dan $\mathrm{F}_{3} 95,57 \%$. Evaluasi sediaan menunjukkan tidak adanya perubahan yang signifikan pada viskositas dan waktu emulsifikasi drop liquid SNEDDS Astaxanthin setelah melalui uji stabilitas selama 28 hari dengan menggunakan analisis data Paired T-Test $(\mathrm{p}<0,05)$.

\section{Referensi:}

[1] Abdullah , Dorothy, E. R., \& Uripto. (2010). Penentuan Waktu Reaksi Dan Jumlah Katalis Optimum Pada Pembuatan Biodisel Dari Minyak Goreng Bekas. Info Teknik Volume 11 No 1, 24-36.

[2] Borlongan, , C. K., Kanning, K., \& Poulos, S. G. (1996). Free Radical Damage And Oxidative Stress In Huntington's Disease. J. Fla. Med.Assoc, 335-341.

[3] Date, A. A., Desai, N., Dixit, R., \& Nagarsenker. (2010). Self Nano Emulsifying Drug Delivery Systems: Formulation Insights, Applications And Advances. Nanomedicine, 1595-1616.

[4] Huda, N., \& Iis Wahyuningsih. (2016). Karakterisasi Self-Nanoemulsifying Drug Delivery System (Snedds) Minyak Buah Merah (Pandanus Conoideus Lam.). Jurnal Farmasi Dan Ilmu Kefarmasian Indonesia, 49-57.

[5] Indriani, V., Novita Eka Kartab Putri Tobing, \& Laode Rija. (2018). Formulasi SelfNanoemulsifying Drug Delivery System (Snedds) Ekstrak Biji Ramania (Bouea Macrophylla Griff) Dengan Asam Oleat Oleic Acid) Sebagai Minyak Pembawa. Mulawarman Pharmaceuticals Conferences, 276-284. 
[6] Jyonouchi, H., Sun , S., \& Gross, M. (1995). Effect Of Carotenoids On In Vitro Immunoglobulin Production By Human Peripheral Blood Mononuclear Cells Astaxanthin, A Carotenoid Without Vitamin A Activity, Enhances In Vitro Immunoglobulin Production In Response To A T-Dependent Stimulant And Antigen. Nutr. Cancer, 171-183.

[7] Kaur, G., Pankaj, C., \& Halikumar, S. L. (2013). Formulation Development Of Selfnanoemulsifying Drug Delivery System (Snedds) Of Celecoxib For Improvement Of Oral Bioavailability. Pharmacophore, 120-133

[8] Makadia, H. A., Bhatt, A. Y., Parmar, R. B., Paun, J. S., \& Tank, H. M. (2013). Selfcnano Emulsifying Drug Delivery System (Snedds): Future Aspect. Asian Journal Of Pharmaceutical Research., 21-27.

[9] Nugroho, B. H., \& Sari, N. P. (2018). Fomulasi Self Nano Emulsifiying Drug Delivery System (Snedds) Ekstrak Daun Karamunting (Rhodomyrtus Tomentosa (Ait.) Hassk). Jurnal Ilmiah Farmasi (Jif), 1-8.

[10]Nurdianti, L., Aryani, R., \& Indra. (2017). Formulasi Dan Karakterisasi Sne (Self Nanoemulsion) Astaxanthin Dari Haematococcus Pluvialis Sebagai Super Antioksidan Alami. Jurnal Sains Farmasi \& Klinis, 30-36.

[11] Otarola, J., Lista, A. G., Fernández Band, \& Garrido, M. (2015). Capillary Electrophoresis To Determine Entrapment Efficiency Of A Nanostructured Lipid Carrier Loaded With Piroxicam. Journal Of Pharmaceutical Analysis, 70-73.

[12]Sahumena, M. H., Suryani, \& Neni Rahmadan. (2019). Formulasi Self-Nanoemulsifiying Drug Delivery System (Snedds) Asam Mefenamat Menggunakan Vco Dengan Kombinasi Surfaktan Tween Dan Span. Journal Syifa Sciences And Clinical Research, 37-46.

[13]Sharma , V., Pratiush Saxena, Lalit Singh, \& Pooja Singh. (2012). Self Emulsifying Drug Delivery System; A Novel Approach. Journal Of Pharmacy Research, Vol 5.

[14]Tulandi, G., Sri , S., \& Widya, A. (2015). Validasi Metode Analisis Untuk Penetapan Kadar Parasetamol Dalam Sediaan Tablet Secara Spektrofotometri Ultraviolet. Manado: Pharmacon Jurnal Ilmiah Farmasi .

[15]Wirnarti, Suwaldi, Matin, \& Hakim. (2018). Formulation Of Insulin Self Nanoemulsifying Drug Delivery System And Its In Vitro-In Vivo Study. Indonesian J. Pharm. Vol. 29, No. 3, 158166. 